\title{
Twenty-First Century Skill Building for Homeschooled Students With Special Needs
}

\author{
Jami M. Tipton, PhD \\ The Cardinal School, Madison, Alabama, United States \\ iD https://orcid.org/oooo-0001-7396-0780
}

Contact: tiptonjami@yahoo.com

\begin{abstract}
Although problem-based learning (PBL) is not new, the ways in which homeschool teachers use attributes of PBL with their students with special needs is unknown. Posts were collected from 20 homeschool teachers' blogs. After I coded 87 blog posts, results showed that homeschool teachers provided a variety of opportunities for their students to practice 21st-century skills. Specifically, they developed lessons that encouraged students to share what they learned and developed cross-disciplinary content, most often with language arts. Results may provide insights for homeschool teachers interested in more purposefully implementing PBL experiences with the purpose of teaching 21st-century skills.
\end{abstract}

Keywords: 21st-century skills, students with special needs, communication and collaboration, cross-disciplinary knowledge, homeschool teachers, social media, educational blogging

Date Submitted: July 17, 2020 | Date Published: September 24, 2021

Recommended Citation

Tipton, J. M. (2021). Twenty-first century skill building for homeschooled students with special needs. Journal of Educational Research and Practice, 11(1), 232-248. https://doi.org/10.5590/JERAP.2021.11.1.17

\section{Introduction}

According to Russell (2017), the number of homeschooled students in the United States has increased by $62 \%$, and the numbers continue to climb. With recent changes in the ways that schools have chosen to provide instruction, there are many students attending school at home but receiving their instruction from local public schools. Homeschool teachers in this study are defined as parents who have chosen to provide school at home for their students. When parents of a student with special needs perceive that their student's special educational needs are not being met, they choose to homeschool (Morse \& Bell, 2018). The decision to homeschool allows them to be more involved in their children's education (Morse \& Bell, 2018). Due to flexibility and individualized instruction that is available, students with special needs experience more success and motivation and are more actively engaged (Liberto, 2016; Thomas, 2017). While statistics show an increase in the number of homeschooling families, little is known about how homeschool teachers of students with special needs teach 21st-century skills. Using a learning approach such as problem-based learning (PBL) with students with special needs gives them more success in the classroom due to hands-on and authentic learning experiences that take place (Duda, 2014). Little is known about how homeschool teachers use PBL with students with special needs. 
The learning experiences provided in PBL environments have been referred to under a variety of terms, including experiential learning (Haines, 2016; Scogin et al., 2017), active learning (Leo \& Puzio, 2016; Mueller et al., 2015; Siew \& Mapeala, 2017), or constructivism (Lee \& Hannafin, 2016; Toppel, 2015). PBL is an umbrella term for both problem- and project-based learning, making the definition not always easy to determine; therefore, to make clear which was used in this study, a discussion of the critical elements of problem-based learning follows. Merritt et al. (2017) defined PBL as an instructional method that is used to help students develop the ability to apply their knowledge to real-world settings by working together on meaningful problems (p. 4). PBL is described in different ways, but a review of the literature shows that PBL had a number of unifying characteristics. For the purpose of this study, learning experiences that include the following three elements were considered PBL: (a) centered around a challenging problem (Brassler \& Dettmers, 2017; Hung, 2016; Larmer et , 2015), (b) authenticity (Larmer et al., 2015; Siew \& Mapeala, 2017; Stefanou et al., 2013), and (c) student voice and choice (Larmer et al., 2015; Sahin \& Top, 2015).

\section{Problem-Based Learning in Homeschooling}

The implementation of PBL in the classroom is not a new approach. Research shows that homeschool teachers do not often use the term PBL but apply similar experiences in STEM (Gann \& Carpenter, 2018), individualized or student-directed instruction (Efford \& Becker, 2017; Thomas, 2016), real-world learning applications (Liberto, 2016), or literature-based instruction (Gann \& Carpenter, 2018; Thomas, 2017). PBL is often taught using a multidisciplinary approach (Livstrom et al., 2019), but may not be easy to implement with larger groups (Lewis et al., 2019). The multidisciplinary approach is likely more common in the homeschool classroom; however, little research has been done on PBL in homeschool settings.

The PBL method allows homeschool teachers to work with students of various ages who each learn at their own pace while learning topics that meet both students' interests and state guidelines (Thomas, 2016). For example, in one study, a homeschool teacher developed a series of science and literary activities based on her daughter's newfound interest in tadpoles (Efford \& Becker, 2017). Homeschooling environments allow for this kind of learning to take place daily, but it may not be as easy to implement in a traditional learning environment. In their study and based on their personal experiences as homeschool teachers, Efford and Becker (2017) explained that by implementing a student-centered learning approach, such as PBL, students' interests could be used as a tool to expand on prior knowledge and experiences. By engaging in teachable moments with their students, teachers are able to provide a homeschool learning environment that meets the individual needs of their student(s) (Efford \& Becker, 2017). Having the freedom to embrace teachable moments while their student or students are interested in a particular real-world problem or topic allows homeschool teachers to focus on students' specific needs and interests; thereby, providing them with the opportunity to learn naturally (Efford \& Becker, 2017). This type of engagement leads to improved communication and collaboration skills (Efford \& Becker, 2017; Hall \& Miro, 2016; Hwang et al., 2015). Effective PBL meets students "on the edge of prior knowledge and leads him or her into new knowledge by connections through that prior knowledge" (Efford \& Becker, 2017, p. 38).

Homeschooling teachers who prefer to individualize instruction and use self-directed studies may implement STEM to promote an authentic learning environment using elements of PBL. Homeschool teachers are drawn to STEM education because it promotes collaboration between students and their parents as well as homeschool students (Gann \& Carpenter, 2018). In a study of 29 homeschool teachers, results showed that STEM strategies enabled them to customize their instruction to meet the individual needs and interests of their students (Gann \& Carpenter, 2018). Teachers appreciated how individualized and self-directed learning gave their students practice with collaboration skills and application of real-world problems. They discovered that when using a variety of learning methods, they better understood students' learning styles and felt that encouraging students to engage in research and exploration of topics that were relevant to them allowed students to make more connections between what they are learning and the real world. 
Last, homeschooling teachers who prefer more structure might organize learning environments differently. They may use a combination of boxed, student-led, and literature-based curriculum to meet students' individual needs, while also keeping some elements of traditional approaches (Gann \& Carpenter, 2018; Thomas, 2017). This freedom to choose learning approaches that best fit their students' needs allows homeschool teachers to use diverse methods of instruction (Thomas, 2017). Some homeschool teachers who use literature-based approaches may have students read novels such as The Adventures of Huckleberry Finn to teach students a particular time period but in a way that is more meaningful to students. Programs such as Sonlight (http://www.sonlight.com) or books such as Currents in Literature provide teaching resources for homeschool teachers to teach cross-disciplinary topics using literature as the foundation. Still, others strictly use PBL. In such environments, a combination of resources and learning tools are used, such as videos, hands-on activities, experiments, and texts to customize students' specific learning needs (Gann \& Carpenter, 2018). Studies show that homeschool teachers have the flexibility to implement a variety of instructional methods to provide their students with a more individualized and authentic learning experience (Bell et al., 2016; Carpenter \& Gann, 2016, 2017). Despite the challenges found when implementing PBL, teachers may find that the benefits can outweigh the negatives. Homeschool teachers Liberto and English (2016) found that using real-life experiences within their instructional time appeared to mitigate learning difficulties. More traditional approaches to learning restrict students from engaging in learning based on their interests (Liberto \& English, 2016). The interest-inspired and authentic learning that is found in a PBL environment promotes learning and often reduces learning difficulties (Liberto \& English, 2016).

\section{Teaching 21st-Century Skills}

Students of all ages and abilities need a learning environment that enables them to develop 21st-century skills necessary for success both in and out of the classroom. While all 21st-century skills are important, the focus for this study was on (a) communication and collaboration and (b) cross-disciplinary knowledge. The literature does not include empirical research of homeschool students with special needs in relation to learning 21st-century skills. Therefore, this portion of the literature review focuses on research with classroom teachers and students.

\section{Communication and Collaboration}

Communication is the ability to clearly state thoughts and actively listen (Kereluik et al., 2013). Communicating thoughts and ideas can happen verbally, in writing, and/or using other multimodal communications. Collaboration is the ability to work effectively with others to reach a common goal (Dole et al., 2016; Germaine et al., 2015). Communication and collaboration have been found to be challenging skills for diverse learners, especially those with special needs. In an ethnographic case study exploring the various pedagogies used in two special education middle school mathematics classrooms, Lambert (2015) found that students learned to make more connections with content and their peers when engaged in a learning environment that focused on student-to-student and student-to-teacher collaboration and communication. While working with students with special needs in the regular classroom, the special education teacher encouraged students to work independently but also to discuss freely and work together when needed (Lambert, 2015). As a result, students learned that they could effectively communicate even though they had previously been denied opportunities based on labels (Lambert, 2015). O'Keeffe and Medina (2016) found, while working with a diverse population of middle school students, that students learned best when provided with a learning environment that promoted active learning and collaboration. Providing students with opportunities to engage in collaborative learning encourages the development of 21st-century learning skills, communication, and collaboration.

When a learning environment is created that allows students to engage in authentic learning tasks and encourages the development of important 21st-century learning skills, students of all ability levels can excel. Duda (2014), an associate professor of quantum physics, shared his anecdotal experiences of using PBL. No 
special accommodations were made for the lower-achieving students, although Duda found that because they were able to engage in projects and problems based on real-world scenarios, they were more in tune with what they were learning, motivating them to find answers. Although students were able to work independently, projects encouraged communication and collaboration with peers to help students solve problems. Gothberg et al. (2016) discussed the importance of developing the 21st-century skill of communication and collaboration with students with special needs and found success with developing purposeful goals related to these skills. Effective communication and collaboration are often a challenge for lower-achieving students; therefore, providing motivational scaffolding for students may help improve their ability to solve PBL challenges and learn important 21st-century skills (Kim et al., 2019).

\section{Cross-Disciplinary Knowledge}

Cross-disciplinary knowledge is "knowledge that integrates and synthesizes information from across fields or domains" (Kereluik et al., 2013, p. 130). Kereluik et al. (2013) stated that this type of knowledge requires students to comprehend and connect data or information that they obtain through various resources. Brassler and Dettmers (2017) explained that not only do students learn more effectively when involved in the PBL model, their cross-disciplinary knowledge is also enhanced. When students use cross-disciplinary knowledge to solve real-world problems, they gain a deeper understanding of problems.

Activities that engage students in terms of building on different content knowledge teach them new concepts in ways that are relatable to them. Research shows that broad or specific themes used in cross-disciplinary studies facilitate learning and keep students actively engaged (Moyer, 2016). Students who are engaged in PBL activities have new opportunities for developing cross-disciplinary knowledge. Although Sochacka et al. (2016) did not study homeschool students with special needs, they found that crossing STEM learning with art when teaching about waste gave students a more "holistic and connected understanding" of a real-world engineering problem (p. 33). By crossing disciplines, students are able to improve their skills of using prior knowledge from other content areas to solve a variety of problems. Implementing STEM education as well as crossing other content areas engages students in hands-on activities, increases motivation, and allows students to make connections with real-world problems (Hwang \& Taylor, 2016). Hwang and Taylor (2016) stated that "although there is a significant lack of research about STEM education for students with disabilities, researchers have started to pay attention to how meeting their special needs can fit into the design of instructional plans" (p. 42).

Hsu and Lee (2015) said elementary students gained cross-disciplinary knowledge through combining computer-supported PBL collaborative learning activities in the science classroom. In this science classroom, students used online gamification, thereby building their cross-disciplinary knowledge through social networking and IT skills, as well as learning essential science content (Hsu \& Lee, 2015). STEM activities naturally require students to develop knowledge and complete projects across multiple disciplines. Implementing STEM activities in elementary classrooms encourages students to build their cross-disciplinary knowledge through the merging of science and math ideas to solve a problem or develop a project (English \& King, 2015). Learning in a classroom that uses multiple disciplines in one project or solves a real-world problem allows students to build on their strengths and prior knowledge, which could result in deeper learning. Middle school students were engaged in a PBL project called Tour America, in which they became concert tour managers for a fictional band that was preparing to begin a yearlong U.S. tour (Hill, 2014, p. 453). This type of learning opportunity allowed students to use multiple content areas, such as language arts, math, and technology to effectively complete their projects. Interdisciplinary projects such as Tour America allow students to use prior knowledge while still gaining real-world experiences. Broad or specific themes used in cross-disciplinary studies facilitate learning and keep students actively engaged (Moyer, 2016). Students who are engaged in PBL activities have new opportunities for developing cross-disciplinary knowledge. 
Activities that engage students in terms of using and building on different content knowledge can be used to teach them new concepts in a way that is relatable to them. In one study, an engineering teacher partnered with an art teacher to provide their students with a more creative way of learning STEM content (Sochacka et al., 2016). By crossing STEM learning with the arts, teachers encouraged students to think more creatively by drawing prior knowledge from both content areas. Through this study, these teachers found that using crossdisciplinary learning while teaching about waste allowed students to gain a more "holistic and connected understanding" of a real-world engineering problem (Sochacka et al., 2016, p. 33). As is seen in this study, providing students with learning activities that cross multiple disciplines gives them opportunities to learn concepts in which they may have otherwise struggled. The literature has shown that students benefit from cross-disciplinary units and can improve their skills of pulling what they learn from different subjects to solve a variety of problems, thereby acknowledging the importance of providing students with learning opportunities that cross content areas.

\section{Homeschooling Students With Special Needs}

Varying experiences with traditional school settings as well as family situations lead families to homeschool (Neuman \& Guterman, 2017). Homeschooling has shown to be highly beneficial for students with special needs (Cheng et al., 2016; Thomas, 2016). Homeschooling is not an easy task, especially when teachers take on the responsibility of educating students with special needs. In a qualitative study, Thomas (2016) examined the routines and experiences of homeschool teachers and found that they were highly motivated to provide quality education for their students, carefully choosing best instructional approaches and curriculum. Homeschool teachers expressed excitement about having the flexibility to plan their academic day around the special needs and interests of their students. The flexibility and freedom that homeschool teachers experience keeps them and their students motivated and engaged (Liberto, 2016; Thomas, 2016, 2017). Although parents have a lot of responsibility when homeschooling, both homeschool teachers and students experience excitement and motivation due to the freedom to learn based on their interests while using individualized approaches. In an autoethnographic study, a homeschool teacher explained how her experiences of homeschooling her student with special needs gave her and the student a new outlook or perception of education (Liberto, 2016). Through her study, Liberto (2016), a homeschool teacher, found that said studentled and interest-inspired learning promotes learning and emotional wellbeing, resulting in less severe learning difficulties. Traditional learning can often be tiresome, overwhelming, and ineffective, resulting in low self-esteem and poor mental health (Liberto, 2016). Authentic and meaningful learning enables families to grow and learn together (Liberto, 2016). This homeschooling teacher's experiences showed that when using a more flexible, authentic, and individualized learning approach, teachers can make students with special needs feel supported both academically and emotionally (Liberto, 2016). The flexibility and freedom that homeschool teachers experience allow them to create a learning environment in which their students can use and build on their strengths to overcome challenges while having fun throughout the learning process. Homeschool teachers' perception is that the decision to homeschool allowed them to provide a more individualized, authentic learning experience for their students, which provides more benefits for students with special needs (Cheng et al., 2016).

\section{Social Media as Public Pedagogy}

Teachers use social media for more than finding ideas for lesson and learning tasks. Teachers use social media and Web 2.o technologies as another form of professional development and to create personal learning networks (Reilly, 2017). These types of online educational spaces have been called public pedagogy (Dennis, 2015). Educational blogs are a part of online networks where people "coalesce around them to understand themselves and each other, in relation to policy, pedagogy and the purposes of education" (Wilson et al., 2015, p. 2). Blog authors are able to articulate and share their experiences, and this type of data is conducive for 
qualitative examination (Wilson et al., 2015). Teachers are using these public platforms as a way to reflect, share, and learn (Carpenter et al., 2017).

\section{Method}

The purpose of this study was to explore how publicly shared PBL experiences of homeschool teachers who work with students with special needs reflect 21st-century skills of (a) communication and collaboration and (b) cross-disciplinary knowledge. The topic of this investigation was experiences of homeschool teachers implementing PBL with students with special needs and how these reflected 21st-century skills. In this study, homeschool teacher blogs were used as sources of data to better understand the public pedagogy of homeschool teachers of students with special needs. Using social media posts as archival data is a methodological way to access community beliefs, attitudes, and behaviors of previously hard-to-reach populations (Clark et al., 2019). When using blogs as data, the anonymity of authors may raise issues about whether public content is authentic and true, and confirming identity may be impossible (Wilson et al., 2015). However, for this study, I deemed blog posts maintained by self-proclaimed homeschool teachers adequate data sources, as they provided valuable insight into what teachers share about their experiences. Therefore, blog data in this study were analyzed via the context of the storytelling narrative in terms of what homeschool teachers describe about their teaching and learning experiences.

For this study, I employed content analysis using publicly available blog posts to determine if and how homeschool teachers of students with special needs teach 21st-century skills through PBL. Two research questions guided my study:

1. How do publicly shared experiences of homeschool teachers implementing PBL with students with special needs reflect the 21st-century skill of communication and collaboration?

2. How do publicly shared experiences of homeschool teachers implementing PBL with students with special needs reflect the 21st-century skill of cross-disciplinary knowledge?

\section{Data Collection}

This qualitative content analysis study was completed through a public search of blog posts from 19 homeschool teachers who work with students with special needs. To begin data collection, I identified blogs that met my three inclusion criteria: (a) written by a homeschool teacher, (b) identified that a student with special needs was being homeschooled, and (c) had a minimum of three posts that referenced teaching and learning that align with the fundamentals of PBL, posted at least two months apart. I did not try to determine a homeschooling parent's educational background or training, nor did I search for evidence of official determination of the child's special need. My inclusion criteria were that the blog author publicly claimed to be homeschooling their child with special needs.

I started on the "About Me" pages of blogs and followed links as provided to determine whether the blog fit the first two inclusion criteria. For the last inclusion criterion, I looked for dates of blog posts that aligned with fundamentals of PBL. Through the literature review, I recognized that homeschool teachers do not often use the term PBL and therefore had predetermined search terms that would help me identify similar activities and skills described in the PBL literature. I used the search feature located on each blog site and a variety of search terms to identify 19 blogs that fit all three criteria. These 19 blogs make up the study's sample.

As I found blog posts, I recorded URLs in which PBL search terms led me to posts. Some homeschool teacher blogs had more than three posts related to PBL activities, and these were included for data analysis. I collected 
between three and nine blog posts from 19 different homeschool teacher blogs. A total of 86 blog posts were identified as meeting study criteria and were included for data analysis. Additional descriptive data were collected including homeschool teachers' philosophy of homeschooling, number of children being homeschooled, identified special needs, and religious affiliation, if any.

\section{Data Analysis}

I first used theory-driven, a priori codes (see Ryan \& Bernard, 2003) organized in a codebook as recommended by DeCuir-Gunby et al. (2011). These a priori codes were developed prior to coding and aligned with the conceptual framework and literature related to 21st-century skills. I entered all 86 blog post narratives into the coding software Dedoose. The following descriptors were added for each blog author: (a) blog code, (b) teaching philosophy, (c) special needs, (d) number of students being homeschooled, and (e) religious affiliation. Dedoose allowed me to assign a priori codes to text excerpts. Coding was completed by the author, and I coded all 86 blogs twice, and then calculated an intracoder reliability score. I calculated a Cohen's kappa score for all of the codes. For codes to have a score showing satisfactory agreement, a kappa score that falls between 0.4 and 0.6 is preferred (MacPhail et al., 2016). For those codes that had a kappa score lower than 0.4, I read through the data again and made adjustments to assigned codes, adjusting the codebook to align. The kappa score was recalculated and a final score of 0.46 showed satisfactory agreement between coding sessions, therefore providing intrarater reliability between both rounds of coding. I completed the coding and conducted a second level of coding to analyze blog data through constant comparisons to find similarities and differences among Level 1 codes as recommended by Merriam and Tisdall (2016). These patterns and themes allowed me to develop emergent or data-driven codes that emerged from raw data used for the study (see Ryan \& Bernard, 2003).

\section{Results}

Findings from my study showed that homeschool teachers publicly shared that they provide their students with special needs a variety of ways to share what they learn but did not incorporate many opportunities for these students to collaborate with others. Findings indicated that homeschool teachers shared activities and assignments that required their students with special needs to apply knowledge across multiple disciplines. While I coded and analyzed blog texts word-for-word, for data reporting I paraphrased ideas from blog posts instead of using exact quotes. Roberts (2015) stated that even when using publicly available data in research, researchers should treat subjects as humans and take great care to prevent others from locating their identities. Therefore, I chose to paraphrase ideas rather than use quotes from blogs to protect homeschool teachers from being identifiable via search engines. I present findings organized by emergent themes for each research question.

\section{Communication and Collaboration}

Teachers shared ways they provided their students with opportunities to connect with experts regarding their specific interests. For example, Teacher $\mathrm{P}$ shared how she and her students took a beekeeping class in which they were able to communicate and interact with an adult who was an expert on something they wanted to learn about. Teacher $\mathrm{M}$ shared how she connected her students with a friend who was knowledgeable about nature to go with them on nature walks. She explained this helped connect her students with experts who may have information and passion apart from what they know.

\section{Visual Sharing}

For the emergent code of visual sharing, teachers shared a variety of methods they used to have students share what they had learned in a visual way. For example, Teacher A had her students create a reptile habitat, where 
students had to show that they had a clear understanding of where reptiles were found and various climates and terrains they needed to survive.

\section{Verbal Sharing}

Teachers shared a variety of ways they had students share what they had learned verbally, such as oral presentations and informal discussions. For example, during a STEM activity, Teacher $\mathrm{C}$ had her students design, build, and test miniature boats. The teacher then engaged students in a discussion to explain the best and worst parts of their designs and how they could be improved. Another teacher, during a Viking unit study, had her students choose a famous Viking and give an oral report.

\section{Collaborate/Work Together}

Teachers shared a variety of methods they used to allow students to collaborate with their siblings or others to complete a specific project or task. For example, Teacher $\mathrm{H}$ and her students decided to raise chickens. As a group, students had to determine a budget and work together to design and build a chicken coop. Teacher B also shared ways that she provides her students the ability to practice collaborating related to solving problems. When her students come to her with a problem, she asks them questions and encourages them to brainstorm ways they can solve the problem together.

\section{Connecting With an Expert}

Teachers shared ways they provided their students with opportunities to connect with experts regarding their specific interests. Such opportunities included meeting with computer shop owners or beekeepers to learn more about a specific topic. For example, Teacher P shared how she and her students took a beekeeping class in which they were able to communicate and interact with an adult who was an expert on something they wanted to learn about. Teacher M shared how she connected her students with a friend who was knowledgeable about nature to go with them on nature walks. She explained this helped connect her students with experts who may have information apart from what they know.

\section{Cross-Disciplinary Knowledge}

Cross-disciplinary knowledge is the 21st-century skill addressed in the second research question. A wide variety of cross-disciplinary activities were shared on homeschool teacher blogs. I discuss these in terms of those activities that integrated language arts (LA) skills and those that did not.

\section{LA Across Disciplines}

Teachers publicly shared lessons they did with students with special needs that combined LA with history, math, art, or science. LA was most often combined with history lessons. Teachers shared a variety of ways students used knowledge from both LA and history to complete a task or solve a problem. Teacher R used the book The Lord of the Rings to include both literary analysis and medieval British literature activities. Similarly, Teacher N used a fantasy series to teach history and LA concepts. Her students read Magic Tree House books that gave facts about ancient India, the Taj Mahal, elephants, and cobras. Since there were several cases where bad sentence structure was noticed, she also used this series to teach about sentence fragments and run-on sentences. Teacher Q shared how she used a documentary on Napoleon to address history, grammar, and writing assignments for her student.

Math was also sometimes combined with LA. Teacher D shared how using the numbers in Pi as an inspiration to have her students write a story. She shared more generally how there were several books about Pi and other math concepts that could be used to increase reading skills while also addressing various math concepts. Math and LA concepts can be taught simultaneously to any age group. While Teacher D shared ideas for older students, Teacher I said she incorporated both subjects for her early grade school students. For instance, Teacher I shared how she used the book The Gnome's Gemstone to introduce numbers 1-12, as well as 
addition, subtraction, multiplication, and division. Each lesson built on the previous lesson and was a great read-aloud that added fun to what they were learning. Art was also combined with LA activities and projects. During a Middle Ages unit, Teacher D had students make their own clothing to wear from that time period. Teacher Q said she used books to develop appropriate crafts for students. While some teachers used books or research along with art activities, some also incorporated writing skills into these activities. For example, Teacher K said students like to create invitations using their favorite manipulatives.

During other lessons, science was combined with LA. Teacher O shared how during a study on climates and biomes, her student decided to write a graphic novel that illustrated differences between different biomes and included the weather, flora, and fauna for each. Teacher $\mathrm{S}$ had students who decided to write and draw pictures about what they learned in regard to nature in a journal. Teacher M said students completed a creative writing activity on rock formations, and Teacher D had students read the book The Secret Garden, after which they could make their own terrarium.

\section{Non-LA Across Disciplines}

Teachers also publicly shared lessons that combined history/art, math/science, science/art, and science/history. For those not related to LA, I found the emergent themes history/art, math/science, science/art, and science/history. For the emergent theme history/art, teachers shared a variety of methods where they used both history and art in projects and activities. Teacher Q said she engaged her students in a drawing activity by having them draw the flag of each country they studied. While some teachers incorporated art through drawing activities, others had their students make actual historical objects. For instance, Teacher D said that when studying WWII, instead of having students read about types of planes that were used, having them construct one made learning history more exciting. Students were able to make history hands-on by making their own WWII plane. Other teachers included technology. For example, Teacher D shared how students could build within the Middle Ages part of the Minecraft game. Since so many parts of every field are done via technology, this text excerpt is a good example of history/art because not only will students learn about the Middle Ages but they will also gain important 21st-century skills related to technology.

For the emergent theme math/science, teachers shared a variety of methods in which they used both math and science in projects and activities. For example, during a science unit on apples, Teacher I shared that after students learned about various kinds of apples, she had them ask each family member what their favorite kind of apple was and then create a bar graph showing the results. After students learned about different kinds of apples, they took surveys and put results into a bar graph, which is an essential math skill for students. Teacher I said that within that same unit they could bake an apple pie together, which would incorporate fractions and measurement. After students learned about apples, they could apply math concepts such as fractions and measurements. Teacher A said her oldest student built their first computer with help and later moved on to master an executive function exercise planning a computer build for a friend. This led to including more math involving budget spreadsheets for new builds and analysis of cost versus performance for each computer build. The student used math skills to complete a real STEM-related project.

For the emergent theme science/art, teachers shared a variety of methods in which they used both science and art in projects and activities. Teacher $\mathrm{O}$ said during a study of friction, a spontaneous art project emerged. In this project, her students first timed how quickly marbles rolled down plain paper, and then dotted the paper with paint and rolled the same marbles down to compare differences in time. Students were not only engaged in a science experiment on friction, but included an art activity by adding paint. Teacher $\mathrm{O}$ said when her students were studying paramecium, it led them to create stuffed paramecium out of felt. These students learned via science how to complete an art-related project. After teaching about tectonic plates and volcanoes, Teacher $\mathrm{O}$ shared how her oldest student decided to paint a volcano in watercolors, take a picture of it, and then upload it to an editing program to label its parts. This showed understanding of what had been studied. Teacher A shared how during a unit study of owls, her student learned to draw an owl using chalk pastels. In 
another bird-related unit, Teacher P shared how her student took a sketchbook to the local raptor center and zoo to draw the birds they had studied in their habitats. These students were required to draw birds they had studied both in and outside of their natural habitat. While most teachers shared art activities in relation to drawing or painting, others shared experiments that incorporated art concepts. For instance, Teacher B said they added color mixing to a basic baking soda and vinegar chemical reaction to see what happened. While learning about the chemical reaction involving baking soda and vinegar, they received a brief art lesson about mixing colors.

For the emergent theme science/history, teachers shared a variety of methods in which they used both science history in projects and activities. Science can easily be incorporated into map work and the study of countries. For instance, Teacher A shared how since a student was very interested in reptiles, they incorporated it into their map work and learned where different reptiles could be found. In another post, Teacher A shared how during a unit on birds, they used a map and located the habitats of exotic birds. These students were learning about animals they were interested in, along with where they could be found, which resulted in stronger map skills.

\section{Discussion (Findings as Applied to Literature)}

Findings from this study show that blog posts of homeschool teachers with students with special needs who implement PBL reflect 21st-century skills of communication and collaboration in a number of ways. Data show that like classroom teachers, homeschool teachers who implemented PBL provide students with opportunities to share their learning, both verbally and visually. As part of PBL projects, students in traditional classrooms often communicate visually (Crist et al., 2017) and verbally (Aydin, 2016; Keshwani \& Adams, 2017). Data from this study show that homeschool students may also receive practice using these skills. Findings of this study extend the current literature because homeschool teachers shared how they gave their students opportunities to express what they had learned, showing that homeschool students are being given opportunities similar to classroom students to improve their communication skills while working on PBL activities.

In relation to collaboration, studies showed that some homeschool teachers encourage collaboration like their classroom teacher counterparts (Gann \& Carpenter, 2018; Longo, 2016). This study showed that homeschool teachers provided collaboration in similar ways to classroom teachers. While classroom students work with others in their class during PBL activities (Gann \& Carpenter, 2018), homeschool students often work with siblings. Compared to other 21st-century skills examined in this study, communication and collaboration emerged the least often. This data may confirm that homeschool teachers of students with special needs struggle like their classroom teacher counterparts (Opitz et al., 2018) to find opportunities for students with special needs to practice collaboration skills. Although STEM activities often promote collaboration (Gann \& Carpenter, 2018) and several homeschool teachers shared their STEM experiences, collaboration was often missing from experiences shared in selected blog posts. Since this study did not produce data on how students were collaborating with others, this may mean that homeschool teachers either do not see the importance of building this skill or are not sharing about it in their blog posts.

Data related to my second 21st-century skill showed that homeschool teachers are providing opportunities for improving cross-disciplinary knowledge with their students with special needs. Data showed that homeschool teachers who applied a teaching philosophy concerning literature shared more about cross-discipline content than other teaching philosophies identified in this study. This may mean that this type of teaching philosophy provides more opportunities for homeschool teachers to use multiple subjects simultaneously. Research shows that, like homeschool teachers, classroom teachers are finding more ways to incorporate related literature when teaching multiple subjects. For example, Brugar and Whitlock (2019) said that when given the 
freedom to do so, fifth grade teachers purposefully chose texts that allowed them to integrate LA into their history instruction. Another study showed that Classroom teachers incorporate various types of literature into their combined history and geology lessons (Dolphin et al., 2018). Data showed that homeschool teachers often discussed integrating ideas across many different content areas.

This study further supports previous research that showed classroom teachers often teach communication and collaboration skills within multiple subject areas (Duda, 2014; Gothberg et al., 2016; Lambert, 2015; O'Keeffe \& Medina, 2016). An interesting finding from this study was that more of the selected homeschool teachers shared their experiences with cross-discipline content using LA in conjunction with another content area. History was the next most-taught content area. Data showed that science was shared more in homeschool teachers' blog posts when taught in conjunction with LA. In a review of the literature on the 21stcentury skill cross-disciplinary knowledge, high school students were often engaged in activities that combined content areas of either LA and history or science and LA (Chung et al., 2017; DiCamillo, 2015; English \& King, 2015). The literature showed that students engaged in units combining historical topics and LA concepts were better able to develop their writing and communication skills regarding the topic they were studying. It also showed that students were more actively engaged (Moyer, 2016). Results from this study confirm the current literature showing that homeschool teachers also are developing the 21st-century skills of communication and collaboration while teaching multiple disciplines.

\section{Conceptual Framework}

The conceptual framework for this study was Kereluik et al.'s 21st-century learning model. Three skills were selected from the model for this study due to how they are associated with skills students build in PBL environments. One conclusion that came from data related to the conceptual framework of this study was that homeschool teachers of students with special needs publicly share their experiences involving providing students with opportunities to develop 21st-century skills. Literature shows that classroom teachers found that the development of 21st-century skills and cross-disciplinary knowledge was important for students with special needs, and PBL is an effective way to incorporate this skill (Habok \& Nagy, 2016; Zhang et al., 2014). Findings from this study confirm that, like classroom teachers, homeschool teachers of students with special needs also provide opportunities for their students to build these skills. Literature shows that when implementing PBL, teachers provide students with more opportunities to engage in real-life, meaningful learning and, as a result, further develop communication and collaboration skills (Lee et al., 2013; Merritt et al., 2017; Scogin et al., 2017). This indicated that skills chosen from Kereluik et al.'s 21st-century learning model were reflected in blog posts of homeschool teachers with students with special needs.

\section{Future Research and Conclusion}

Recommendations for further research are based on study results and the limitations of the study. The first recommendation for future research is to explore why more homeschool teachers use sharing (communication) than connecting (collaboration) in relation to the 21st-century skills communication and collaboration. More research is needed to determine whether homeschool teachers of students with special needs are not providing more opportunities for their students to collaborate with others inside and outside the family or whether this was not a topic they chose to publicly share. The study could be furthered also by examining other 21st-century skills.

The next recommendation is related to how the phenomenon of public pedagogy might influence what teachers post (Dennis, 2015). It is likely that what homeschool teachers choose to post reflects only a portion or possibly embellished interpretation of what they actually do in their homeschool. While bloggers might have altruistic reasons for posting about their schooling, some might have written posts to widen their groups of followers (see Kozinets, 2020). What a homeschool teacher chooses to post is likely with the expectation that their readers want to read it. Therefore, posts about their pedagogy might be influenced by the desire or 
need to post on topics that may bring more traffic to their blogs. Therefore, future studies should include interviews of homeschool teachers and perhaps also include homeschool teachers who do not blog. A netnography study where the researcher becomes a participant observer in a homeschool study online environment would possibly yield additional insights and reduce possible biases involving public pedagogy.

The last recommendation is related to the limitations of this study. This study was done with multiple posts from 19 blog sites of homeschool teachers of students with special needs. While I used 10 blog posts from one teacher's blog site, only three may have been used from another; therefore, future research could focus on equalizing the number of blog posts per homeschool teacher. Equalizing the number of blog posts would provide a more even review of what is being analyzed, removing a single teacher's preferences from the final analysis. I also recommend that the number of posts used should be further equalized in terms of type of identified disabilities from selected homeschool teacher blog sites. Additionally, because activities used to teach skills change to meet the ages and abilities of each student, an analysis done according to student age might provide additional insights regarding how 21st-century skills are being taught to homeschool children with special needs.

Results of this study should encourage more teachers within the homeschool community to implement a PBL approach with their special needs students. The flexibility of schooling at home more naturally allows for teaching out-of-seat skills and cross-disciplinary knowledge. It is evident that homeschool teachers of students with special needs are teaching important 21st-century skills. Results from this study provide insights for homeschool teachers interested in purposefully implementing PBL experiences so that students with special needs receive practice using 21st-century skills. 


\section{References}

Aydin, G. (2016). Impacts of inquiry-based laboratory experiments on prospective teachers' communication skills. International Online Journal of Educational Sciences, 8(2), 49-61. https://doi.org/10.15345/Ionesco.2016.02.005

Bell, D. A., Kaplan, A., \& Thurman, S. K. (2016). Types of homeschool environments and need support for children's achievement motivation. Journal of School Choice, 10(3), 330-354. https://doi.org/10.1080/15582159.2016.1202072

Brassler, M., \& Dettmers, J. (2017). How to enhance interdisciplinary competence-interdisciplinary problembased learning versus interdisciplinary project-based learning. Interdisciplinary Journal of ProblemBased Learning, 11(2). https://doi.org/10.7771/1541-5015.1686

Brugar, K. A., \& Whitlock, A. M. (2019). “I like [...] different time periods:” Elementary teachers' uses of historical fiction. Social Studies Research and Practice, 14(1), 78-97. https://doi.org/10.1108/SSRP08-2018-0033

Carpenter, D., \& Gann, C. (2016). Educational activities and the role of the parent in homeschool families with high school students. Educational Review, 68(3), 322-339.

https://doi.org/10.1080/00131911.2015.1087971

Carpenter, J. P., Cook, M. P., Morrison, S. A., \& Sams, B. L. (2017). “Why haven't I tried Twitter until now?”: Using Twitter in teacher education. LEARNing Landscapes, 11(1), 51-64. https://www.learninglandscapes.ca/index.php/learnland/article/view/922/915

Cheng, A., Tuchman, S., \& Wolf, P. J. (2016). Homeschool parents and satisfaction with special education services. Journal of School Choice, 1O(3), 381-398. https://doi.org/10.1080/15582159.2016.1202076

Chung, C., Cartwright, C., \& DeRose, J. (2017). Robotics festival and competitions designed for STEM+ C education. In M. S. Khine (Ed.), Robotics in STEM education (pp. 131-170). Springer.

Clark, K., Duckham, M., Guillemin, M., Hunter, A., McVernon, J., O’Keefe, C., Pitkin, C., Prawer, S., Sinnott, R., Warr, D., \& Waycott, J. (2019). Advancing the ethical use of digital data in human research: Challenges and strategies to promote ethical practice. Ethics and Information Technology, 21, 5973. https://doi.org/10.1007/s10676-018-9490-4

Crist, C. A., Duncan, S. E., \& Bianchi, L. M. (2017). Incorporation of cross-disciplinary teaching and a wiki research project to engage undergraduate students' to develop informational literacy. Journal of Food Science Education, 16, 81-91. https://doi.org/10.1111/1541-4329.12111

DeCuir-Gunby, J. T., Marshall, P. L., \& McCulloch, A. W. (2011). Developing and using a codebook for the analysis of interview data: An example from a professional development research project. Field Methods, 23(2), 136-155. https://doi.org/10.1177/1525822X10388468

Dennis, C. A. (2015). Blogging as public pedagogy: Creating alternative educational futures. International Journal of Lifelong Education, 34(3), 284-299. https://doi.org/10.1080/02601370.2014.1000408

DiCamillo, L. (2015). Exploring an interdisciplinary expedition in a global history class. The Journal of Social Studies Research, 39, 151-162. https://doi.org/10.1016/j.jssr.2014.12.001

Dole, S. F., Bloom, L. A., \& Doss, K. K. (2016). Rocket to creativity: A field experience in problem-based and project-based learning. Global Education Review, 3(4), 19-32.

Dolphin, G., Benoit, W., Burylo, J., Hurst, E., Petryshen, W., \& Wiebe, S. (2018). Braiding history, inquiry, and model-based learning: A collection of open-source historical case studies for teaching both geology content and the nature of science. Journal of Geoscience Education, 66(3), 205-220. https://doi.org/10.1080/10899995.2018.1475821 
Duda, G. (2014). The road to a project-based classroom. Change: The Magazine of Higher Learning, 46(6), 42-45. https://doi.org/10.1080/00091383.2014.969183

Efford, K. E., \& Becker, K. (2017). Homeschooled students and their teachers: Provoking curriculum together through child-driven learning. Journal of Unschooling and Alternative Learning, 11(22), 34-52. https://jual.nipissingu.ca/wpcontent/uploads/sites/25/2017/12/v11222.pdf

English, L. D., \& King, D. T. (2015). STEM learning through engineering design: Fourth-grade students' investigations in aerospace. International Journal of STEM Education, 2(1), 14. https://doi.org/10.1186/s40594-015-0027-7

Gann, C., \& Carpenter, D. (2017). STEM educational activities and the role of the parent in the home education of high school students. Educational Review, 1-16. https://doi.org/10.1080/00131911.2017.1359149

Gann, C., \& Carpenter, D. (2018). STEM teaching and learning strategies of high school parents with homeschool students. Education and Urban Society, 5O(5), 461-482. https://doi.org/10.1177/0013124517713250

Germaine, R., Richards, J., Koeller, M., \& Schubert-Irastorza, C. (2015). Purposeful use of 21st century skills in higher education. Journal of Research in Innovative Teaching, 9(1), 19-29.

Gothberg, J. E., Peterson, L. Y., Peak, M., \& Sedaghat, J. M. (2016). Successful transition of students with disabilities to 21st century college and careers: Using triangulation and gap analysis to address no academic skills. Teaching Exceptional Children, 47(6), 344-351. https://doi.org/10.1177/0040059915587890

Habok, A., \& Nagy, J. (2016). In-service teachers' perceptions of project-based learning. Springer Plus, 5(83), 1-14. https://doi.org/10.1186/s40064-016-172.5-4

Haines, S. (2016). Feet wet, hands dirty: Engaging students in science teaching and learning with stream investigations. Journal of College Science Teaching, 45(1), 12-17. (ProQuest no. 18145381).

Hall, A., \& Miro, D. (2016). A study of student engagement in project-based learning across multiple approaches to STEM education programs. School Science \& Mathematics, 116(6), 310-319. https://doi.org/10.1111/ssm.12182

Hill, A. E. (2014). Using interdisciplinary, project-based, multimodal activities to facilitate literacy across the content areas. Journal of Adolescent \& Adult Literacy, 57(6), 450-460.

https://doi.org/10.1002/jaal.270

Hsu, K. C., \& Lee, Y. J. (2015). Social gamification in multimedia instruction to advance glacier science for grade k-6 students. In E-Learn: World Conference on E-Learning in Corporate, Government, Healthcare, and Higher Education (pp. 16-21). Association for the Advancement of Computing in Education (AACE). https://www.learntechlib.org/p/152255

Hung, W. (2016). All PBL starts here: The problem. Interdisciplinary Journal of Problem-Based Learning, 1O(2), 2-10. https://doi.org/10.7771/1541-5015.1604

Hwang, G. J., Lai, C. L., \& Wang, S. Y. (2015). Seamless flipped learning: A mobile technology-enhanced flipped classroom with effective learning strategies. Journal of Computer Education, 2(4), 449-473. https://doi.org/10.1007/s40692-015-0043-O

Hwang, J., \& Taylor, J. C. (2016). Stemming on STEM: A STEM education framework for students with disabilities. Journal of Science Education for Students with Disabilities, 19(1), 39-49. https://files.eric.ed.gov/fulltext/EJ1169381.pdf 
Kereluik, K., Mishra, P., Fahnoe, C., \& Terry, L. (2013). What knowledge is of most worth: Teacher knowledge for 21st century learning. Journal of Digital Learning in Teacher Education, 29(4), 127-140. https://www.tandfonline.com/loi/ujdl20

Keshwani, J., \& Adams, K. (2017). Cross-disciplinary service-learning to enhance engineering identity and improve communication skills. International Journal for Service Learning in Engineering, Humanitarian Engineering and Social Entrepreneurship, 12(1), 41-61.

Kim, N. J., Belland, B. R., Lefler, M., Andreasen, L., Walker, A., \& Axelrod, D. (2019). Computer-based scaffolding targeting individual versus groups in problem-centered instruction for STEM education: Meta-Analysis. Educational Psychology Review, 32, 415-461. https://doi.org/10.1007/s10648-01909502-3

Kozinets, R. V. (2020). Netnography: The essential guide to qualitative social media research (3rd ed.). SAGE Publishing.

Lambert, R. (2015). Constructing and resisting disability in mathematics classrooms: A case study exploring the impact of different pedagogies. Educational Studies Math, 89(1), 1-18. https://doi.org/10.1007/s10649-014-9587-6

Larmer, J., Mergendoller, J., \& Doss, S. (2015). Gold standard PBL: Essential project design elements. Buck Institute for Education, 1-4. https://www.pblworks.org/what-is-pbl/goldstandard-project-design

Lee, E., \& Hannafin, M. (2016). A design framework for enhancing engagement in student-centered learning: Own it, learn it, and share it. Educational Technology Research \& Development, 63(4), 707-734. https://doi.org/10.1007/s11423-015-9422-5

Lee, J. S., Blackwell, S., Drake, J., \& Moran, K. A. (2013). Taking a leap of faith: Redefining teaching and learning in higher education through project-based learning. Interdisciplinary Journal of ProblemBased Learning, 8(2), 18-34. https://doi.org/10.7771/1541-5015-1426

Leo, J. \& Puzio, K. (2016). Flipped instruction in a high school science classroom. Journal of Science Education, 25, 775-781. https://doi.org/10.1007/s10956-016-9634-4

Lewis, D. G. R., Gerber, E. M., Carlson, S. E., \& Easterday, M. W. (2019). Opportunities for educational innovations in authentic project-based learning: Understanding instructor perceived challenges to design for adoption. Educational Technology Research and Development, 67, 953-982. https://doi.org/10.1007/s11423-019-09673-4

Liberto, G. (2016). Child-led and interest-inspired learning, home education, learning differences and the impact of regulation. Cogent Education, 3, 1-10. https://doi.org/10.1080/2331186X.2016.1194734

Livstrom, I. C., Szostkowski, A. H., \& Roehrig, G. H. (2019). Integrated STEM in practice: Learning from Montessori philosophies and practices. School Science and Mathematics. https://doi.org/10.1111/ssm.12331

Longo, C. M. (2016). Changing the instructional model: Utilizing blended learning as a tool of inquiry instruction in middle school science. Middle School Journal, 47(3), 33-40. https://doi.org/10.1080/00940771.2016.113.5098

MacPhail, C., Khoza, N., Able, L., \& Ranganathan, M. (2016). Process guideline for establishing intercoder reliability in qualitative studies. Qualitative Research, 16(2), 198-212. https://doi.org/10.1177/1468794115577012

Merriam, S. B., \& Tisdall, E. J. (2016). Qualitative research: A guide to design and implementation (4th ed.). Jossey-Bass. 
Merritt, J., Lee, M. Y., Rillero, P., \& Kinach, B. M. (2017). Problem-based learning in k-8 mathematics and science education: A literature review. Interdisciplinary Journal of Problem-Based Learning, 11(2). https://doi.org/10.7771/1541-5015.1674

Morse, M. L., \& Bell, S. M. (2018). Homeschooling: A growing school choice option for meeting special educational needs. International Journal of Educational Reform, 27(2), 156-172. https://doi.org/10.1177/105678791802700203

Moyer, C. D. (2016). A thematic instruction approach to teaching technology and engineering: Thematic instruction offers flexible opportunities to engage students with real-world experiences in the technology and engineering community. Technology and Engineering Teacher, 76(3), Article EJ1118760.

Mueller, A., Knobloch, N. A., \& Orvis, K. S. (2015). Exploring the effects of active learning on high school students' outcomes and teachers' perceptions of biotechnology and genetics instruction. Journal of Agricultural Education, 56(2), 138-152. https://doi.org/10.5032/jae.2015.02138

Neuman, A., \& Guterman, O. (2017). Structured and unstructured homeschooling: A proposal for broadening the taxonomy. Cambridge Journal of Education, 47(3), 355-371. https://doi.org/10.1080/0305764X.2016.1174190

O’Keeffe, S. B., \& Medina, C. M. (2016). Nine strategies for helping middle school students weather the perfect storm of disability, diversity, and adolescence. American Secondary Education, 44(3), 72-87.

Opitz, E. M., Wittich, C., Hasel-Weide, U., \& Nuhrenborger, M. (2018). Fostering the computation competence of low achievers through cooperative learning in inclusive classrooms: A longitudinal study. Learning Disabilities: A Contemporary Journal 16(1), 19-35. http://www.ldw-ldcj.org

Reilly, C. (2017). Twitter as a professional development tool for teachers and aspiring teachers: A review of literature. National Teacher Education Journal, 1O(2), 57-61.

Roberts, L. D. (2015). Ethical issues in conducting research in online communities. Qualitative Research in Psychology, 12, 314-325. https://doi.org/10.1080/14780887.2015.1008909

Russell, N. (2017, September). Why homeschooling is growing. The Federalist. http://thefederalist.com/2015/09/01/why-homeschooling-is-growing

Ryan, G. W., \& Bernard, H. R. (2003). Techniques to identify themes. Field Methods, 15(85), 109. https://doi.org/10.1177\%2F1525822X02239569

Sahin, A. \& Top, N. (2015). STEM students on the stage (SOS): Promoting student voice and choice in STEM education through an interdisciplinary, standards-focused, project based learning approach. Journal of STEM Education: Innovation \& Research, 16(3), 24-33. Retrieved from Academic Search Complete database. (Accession no. 110317029).

Scogin, S. C., Kruger, C. J., Jekkals, R. E., \& Steinfeldt, C. (2017). Learning by experience in a standardized testing culture: Investigation of a middle school experiential learning program. Journal of Experiential Education, 4O(1), 39-57. https://doi.org/10.1177/1053925916685737

Siew, N. M., \& Mapeala, R. (2017). The effects of thinking maps-aided problem-based learning on motivation towards science learning among fifth graders. Journal of Baltic Science Education, 16(3), 379-394. http://www.scientiasocialis.lt/jbse/files/pdf/vol16/379-394.Siew_JBSE_Vol.16_No.3.pdf

Sochacka, N. A., Guyotte, K. W., \& Walther, J. (2016). Learning together: A collaborative autoethnographic exploration of STEAM (STEM + the Arts) education. Journal of Engineering Education, 105(1), 1542. https://doi.org/10.1002/jee.20112 
Stefanou, C., Stolk, J. D., Prince, M., Chen, J. C., \& Lord, S. M. (2013). Self-regulation and autonomy in problem and project-based learning environments. Active Learning in Higher Education, 14(2), 109122. https://doi.org/10.1177/1469787413481132

Thomas, J. (2016). Learning from homeschooling routines. Journal of Research on Christian Education, 25(3), 233-250. https://doi.org/10.1080/10656219.2016.1237910

Thomas, J. (2017). Parent perspectives: Curriculum and homeschooling approaches. National Home Education Researcher, 33(4). https://www.nheri.org/home-school-researcherparent-perspectivescurriculum-and-homeschooling-approaches/

Toppel, K. (2015). Enhancing core reading programs with culturally responsive practices. Reading Teacher 68(7), 552-559. https://doi.org/10.1002/trtr.1348

Wilson, E., Kenny, A., \& Dickson-Swift, V. (2015). Using blogs as a qualitative health research tool: A scoping review. International Journal of Qualitative Methods, 14, 1-12. https://doi.org/10.1177/1609406915618049.

Zhang, J. W., Wong, L., Chan, T. H., \& Chiu, C. S. (2014). Curriculum adaptation in special schools for students with intellectual disabilities (SID): A case study of project learning in one SID school in Hong Kong. Frontiers of Education in China, 9(2), 250-273. https://doi.org/10.3868/s110-003-014$\underline{0019-x}$ reviewed journal that provides a forum for studies and dialogue about developments and change in the field of education and learning. The journal includes research and related content that examine current relevant educational issues and processes. The aim is to provide readers with knowledge and with strategies to use that knowledge in educational or learning environments. JERAP focuses on education at all levels and in any setting, and includes peer-reviewed research reports, commentaries, book reviews, interviews of prominent individuals, and reports about educational practice. The journal is sponsored by The Richard W. Riley College of Education and Leadership at Walden University, and publication in JERAP is always free to authors and readers. 